\title{
'n Teologiese waardering van die Sinai-tradisie (Eks. 19 - Num. 10:10)
}

\author{
S.D. (Fanie) Snyman \\ Departement Ou Testament \\ Universiteit van die Vrystaat \\ BLOEMFONTEIN \\ E-pos: tlgss@rs.uovs.ac.za
}

\begin{abstract}
A theological evaluation of the Sinai-tradition (Ex. 19 - Num. 10:10).

Among the many and varied angles by means of which the Old Testament are studied, a theological evaluation of it remains valid as there is also need for a global and theological understanding of the Old Testament. This contribution focuses on the theological content of the Sinai-tradition found in Exodus 19 - Numbers 10:10. Furthermore the importance of the Sinai-tradition is pointed out and the literary setting outlined. In this article it is argued that the theological content may be summarized by three concepts: theophany, covenant and Torah.
\end{abstract}

\section{Doelstelling en metodologiese vertrekpunt}

Die Ou Testament is ' $n$ boek met 'n ryk verskeidenheid wat op verskillende maniere oor 'n periode van duisende jare in 'n veelheid van literêre genres oor God en sy verhouding met die skepping in die algemeen en die mens in die besonder praat. Hierdie rykdom perspektiewe het tot gevolg dat die Ou Testament vanuit verskillende invalshoeke gelees en bestudeer kan word: histories, filologies, tekskrities, eksegeties, literêr, sosiologies, feministies, kanonies, godsdiens-histories, teologies, as kulturele artefak, ensvoorts.

'n Beduidende aantal lesers van die Ou Testament lees en bestudeer die Ou Testament vanuit die oortuiging (belydenis) dat dit saam met die Nuwe Testament deel is van God se Woord aan mense. 'n Teologiese lees en verstaan van die Ou Testament is dus ook 'n legitieme en selfs noodsaaklike faset van die bestudering van die Ou Testament. Naas die talle en onontbeerlike detailstudies vanuit watter invalshoek ook al, is daar ook 'n behoefte aan 'n meer globale, teologiese verstaan van die 
Ou Testament. Die onophoudelike stroom publikasies op die gebied van die Teologie van die Ou Testament is ' $n$ verdere aanduiding van 'n behoefte aan 'n teologiese verstaan van die Ou Testament.

In 'n publikasie van Birch et al. (1999) is hierdie behoefte ook uitgespreek. Vier kollegas wat $\mathrm{Ou}$ Testament doseer aan universiteite in Noord-Amerika het dit só gestel:

[We] shared some degree of frustration that the textbooks available for use in introductory courses treated the Old Testament as evidence for the religious experience and witness of ancient communities but seldom as theological resource for comtemporary confessing communities (Birch et al., 1999:11).

Die resultaat hiervan is 'n boek "which seeks to discuss the Old Testament in theological terms ..." (Birch et al., 1999:11).

Wat die vier Amerikaanse kollegas met die Ou Testament as geheel gedoen het, wil hierdie artikel doen met die Sinai-tradisie deur te fokus op die teologiese inhoud van een van die prominente tradisies in die $\mathrm{Ou}$ Testament. Die bedoeling is om die teologiese inhoud van die Sinaigebeure aan te toon 1 . In dié sin poog hierdie bydrae om 'n brug te wees tussen die "toe" (die "ancient communities") van die Sinai-gebeure en die "nou" (die "contemporary confessing communities") van die huidige leser. Die huidige leser word uitgenooi om van die "nou" oor die brug na die "toe" van die Sinai-gebeure te stap en die ontdekking te maak dat die teologiese inhoud van "toe" ook "nou" teologies relevant is.

'n Teologiese verstaan en interpretasie van die Ou Testament is nie onwetenskaplik nie; trouens, dit veronderstel en bou op die wetenskaplike ondersoeke wat van verskillende invalshoeke gemaak is. Historiese, literêre en eksegetiese insigte van die wetenskap van die Ou Testament vorm die boustene waarmee 'n teologiese konstruksie gebou word. Die bou-metafoor is belangrik. Daarmee word gewys op die kreatiewe aard van die aanbieding van 'n teologiese verstaan van die Ou Testament (of 'n gedeelte daarvan). Tegelykertyd word ook die subjektiewe aard van so 'n teologiese konstruksie beklemtoon. Een van die winste van 'n postmoderne bewussyn is juis die erkenning van die subjektiewe aard van alle wetenskaplike werk. Wat hier aangebied word, is 'n subjektiewe, maar ook geldige teologiese konstruksie van die Sinai-gebeure. Binne die beperkings wat geld vir 'n tydskrifartikel spreek dit vanself dat slegs die buitelyne van die teologie van so 'n omvattende deel soos die Sinaitradisie gegee kan word.

1 Die Pentateugkritiek sou dus nie binne die bestek van die artikel ook nog aan die orde kon kom nie. 


\section{Die belangrikheid van die Sinai-tradisie}

Smith (1997:306) maak die volgende opmerking in sy publikasie oor die Sinai-tradisie:

Mount Sinai is the goal of the book of Exodus and it serves as the defining basis for all following standards in the book of Numbers. It is a gross understatement to say Sinai occupies a central place in the priestly theology of the Pentateuch.

Die lyn van verlossing uit Egipte loop op na 'n klimaks met Sinai, en die intog in die land gebeur op grond van die Sinai-gebeure. Childs (1985:53) maak ook die opmerking dat die hart van die Pentateug in die Sinai-gebeure lê (Eksodus, Levitikus en Numeri) en dit wat in die middel van die Pentateug gevind word (vgl. ook Barth, 1991:117 en Jeremias, 1965: 100).

Die belangrikheid van die Sinai-gebeure word verder onderstreep deur die feit dat die vyf boeke van die Pentateug bekend staan as die Tora die Tora wat juis by Sinai gegee is. In die driedeling van die kanon van die Ou Testament in die Tora, Profete en Geskrifte, is die Tora ongetwyfeld die belangrikste deel, in so 'n mate dat die hele Ou Testament die Tora genoem kan word.

Sinai is ook by uitstek die plek waar die verbond tussen Jahwe en sy volk gesluit is. Die verbond as teologiese konsep is 'n belangrike konsep in die Ou Testament. Eichrodt (1975) maak dit selfs die sentrale tema van sy teologie van die Ou Testament. Dat die Nuwe Testament juis die Nuwe Testament genoem word, dui daarop dat die Nuwe Testament gesien word as die nuwe verbond nadat die eerste verbond in Eksodus gesluit is.

\section{Die plek van die Sinai-gebeure in die Pentateug}

Waar staan die Sinai-gebeure in die Pentateug? Smith (1997:305-306) sien 'n chiastiese opbou (ABCBA) in die geheel van die Pentateug:

A Die boek Genesis as proloog

1-11 Die eerste dinge: Die voorgeskiedenis

12-50 Die aartsvaderverhale

B Die Boek Eksodus
1-15:21
Egipte
$15: 22-18: 27$
$19-40$
Die woestyntyd
Sinai 
C Die boek Levitikus

$1-16$

$17-27$

Die handleiding vir die praktyke van die priesters

Die handleiding vir die praktyke van die volk

B Die boek Numeri
1-10:10
Sinai
$10: 11-21: 35$
22-36:13
Die woestyntyd
Transjordanië

A Die boek Deuteronomium

$\begin{array}{ll}\text { 1-11:32 } & \text { Narratief } \\ \text { 12-26 } & \text { Tora } \\ 27-34 & \text { Laaste dinge }\end{array}$

Zenger het in sy boek oor die Inleiding tot die Ou Testament tot dieselfde gevolgtrekking gekom. Volgens Zenger (1996a:37-39) korreleer die volgende: Genesis met Deuteronomium (die belofte van die land en die reëlings vir die lewe in die land word gegee; seën vir die seuns van Israel en die seën van die stamme van Israel; die dood en begrafnis van Jakob en Moses onderskeidelik). Ook Eksodus en Numeri korreleer (Israel op reis in albei boeke, pasga, manna, water uit die rots) en dit maak die boek Levitikus die sentrum van die Pentateug as die boek wat die grondwet van die heilige volk van God genoem kan word.

Uit die geheelsperspektief van die Pentateug is dit duidelik dat die Sinaigebeure die sentrum van die Pentateug vorm. Vanuit 'n ander hoek beredeneer, is dit ook die gevolgtrekking waartoe van Zyl (1992:269) kom: "... Sinai constitues the centre of the whole of the Pentateuch".

Die plek waar die Sinai-gebeure in die Pentateug verhaal word, is teologies gesproke belangrik. Die Sinai-gebeure vind plaas na die uittog uit Egipte (Eks. 1-15) en die omswerwinge in die woestyn (Eks. 16-17). Verlossing gaan dus verpligting vooraf. Jahwe verlos eers sy volk en lê dan verpligtings op sy volk. "Evangelie" (verlossing) gaan die "wet" vooraf. $\mathrm{Na}$ die verlossing uit Egipte waarin die klem volledig val op die inisiatief wat Jahwe geneem het in die verlossing van die volk, volg Sinai waar die verbond gesluit word (weer eens op inisiatief van Jahwe en met beloftes van Hom) en verpligtings op die volk gelê word. Vir Israel is die God wat Hom in majesteit op Sinai aan die volk openbaar en in 'n verbondsverhouding met hulle tree, die God wat hulle uit Egipte bevry het. Die verlossing uit Egipte is dus die fondament vir die besondere verhouding binne die verbond tussen Jahwe en diegene wat verlos is (Zimmerli, 1984:71).

Die standpunt van Von Rad (1975:187) oor die plek van die Sinaigebeure in die heilsgeskiedenis is ook interessant en betekenisvol. Von 
Rad (1975:187-188) het opgemerk dat die Sinai-gebeure konstant ontbreek in die sogenaamde credo's van die Ou Testament (vgl. Deut. 26:59; Jos. 24:2-13; Ps. 105, 106). Uit dié waarneming konkludeer Von Rad $(1975: 187)$ dan dat die Sinai-gebeure 'n latere invoeging in die Heksateug verteenwoordig wat die sogenaamde Kades-tradisie onderbreek. Op hierdie standpunt het Preuss (1995:73) kritiek gelewer deur daarop te wys dat dit in die credo gaan om die heilshandelinge van Jahwe vir sy volk, terwyl dit in die Sinai-gebeure handel oor die verpligtende eise wat Jahwe aan sy volk stel.

Die Sinai-gebeure word vertel vanaf Eksodus 19:1 tot en met Numeri 10:10. Wanneer Eksodus 19:1 en Numeri 10:11-12 gelees word, is dit duidelik dat die gebeure by Sinai omraam word deur die volk se aankoms by en vertrek van Sinai.

Dié gedeelte kan soos volg ingedeel word:

Eksodus 19: $\quad$ Die teofanie by die berg

Eksodus 20-23: Die dekaloog en Verbondsboek (vgl. Eks. 24:7)

Eksodus 24: Die sluiting van die verbond

Eksodus 25-31: Kultiese bepalings oor die aanbidding van Jahwe

Eksodus 32-34: Verbondsverbreking en verbondsherstel

Eksodus 35-40: Verdere kultiese bepalings

Levitikus 1-16: Die handleiding vir die praktyke van die priesters

Levitikus 17-27: Die handleiding vir die praktyke van die volk

Numeri 1-10:10: Sinai

Die boek Deuteronomium as boek wat die verbond tussen Jahwe en sy volk by uitnemendheid beskryf, pas teologies ook in by die gebeure van Sinai. Die boek Deuteronomium is ' $n$ 7de-eeuse hersiening van die Mosaïese tradisie van Israel met 'n spesiale fokus op die sogenaamde Verbondsboek van Eksodus 20:22-23:19.

Die Sinai-gebeure het ' $n$ beduidende invloed op die res van die $\mathrm{Ou}$ Testament. Op verskillende plekke in die res van die Ou Testament word verwys na die Sinai-gebeure: in die boeke van die Vroeëre profete word die ontdekking van die Wetboek in die tempel gedurende die tyd van Josia (2 Kon. 22-3) gesien as een van die hoogtepunte van die geskiedenis. As die profeet in Hosea 4 die volk se sondes opnoem, doen hy dit aan die hand van die Tien Gebooie. Trouens, dit word al hoe duideliker dat die Profete gelees moet word in die lig van die Tora. Hulle is die mense wat die volk teruggeroep het om te leef volgens die bepalings van die Tora as verbondsdokument. Dit is ook nie sonder betekenis nie dat die derde deel van die kanon van die Ou Testament 
begin met Psalm 1 wat vertel van die regverdige wat "in die woord (Tora) van die Here sy vreugde vind" en dit dag en nag oordink. Ook in Psalm 119 vind die regverdige vreugde in die Tora van Jahwe.

Wanneer die materiaal wat in die Pentateug gevind word, van naderby ondersoek word, is dit duidelik dat die Sinai-gebeure saamgestel is uit 'n groot verskeidenheid tradisies. Vanuit histories-kritiese perspektief word gewoonlik onderskei tussen 'n Jahwistiese (Eks. 19-24; 32-34) en 'n Priesterlike (Eks. 25-31; Eks. 35-Num. 10:10) weergawe. By die Jahwis handel dit meer oor die daaglikse profane lewe, terwyl dit by die Priesterbron (P) meer handel oor die verordeninge van die sakrale, kultiese lewe. Die verskeidenheid tradisies word egter aan mekaar verbind deur die gemeenskaplike gegewe, naamlik dat Jahwe bindende bepalings gegee het op grond waarvan 'n lewe voor Hom moontlik sou wees: die plek Sinai en die persoon van Moses (Von Rad, 1975:188).

\section{4. 'n Teologiese perspektief op die Sinai-gebeure}

Die teologiese boodskap van die Sinai-tradisie kan opgesom word met drie trefwoorde: teofanie, verbond, Tora.

\subsection{Teofanie}

Eksodus 19 beskryf die koms van God na sy volk op die Sinai-berg. Die term בשטא ("kom") en ירד ("neerdaal") is terme tipies aan 'n teofanie. Polak (1996:113) maak die opmerking dat die tema van die teofanie 'n dominante tema in die boek Eksodus is. Hy verwys na Moses en die brandende doringbos in Eksodus 3, die klimaks van die Sinai-teofanie, die teofanie van Eksodus 33-34 en die sluiting van die verbond, die wolk wat die tent van ontmoeting oordek en die magtige teenwoordigheid van die Here wat die tabernakel gevul het (Eks. 40:34).

\subsubsection{Die elemente van 'n teofanie}

Die verskyning van God, soos geteken in Eksodus 19, gaan gepaard met 'n reeks natuurverskynsels wat gesien kan word as elemente tipies van die teofanie (Preuss, 1995:67): daar was donderslae en weerlig (19:16), 'n donker wolk $(19: 16,19: 9)$ wat 'n mens laat dink aan 'n donderstorm (Zimmerli, 1984:70), rook en vuur (19:18), die berg wat skud en bewe (Niehaus, 1995:195) soos in 'n aardbewing of 'n vulkaniese uitbarsting (19:18) en die geluid van 'n ramshoring of trompet (19:19). Die elemente wat beskryf word, kan gesien en gehoor word.

Die verwysing na die ramshoring het verskillende interpretasies tot gevolg gehad. Zimmerli (1984:70) dink aan 'n liturgiese seremonie rond- 
om die proklamasie van die dekaloog. Dozeman (1989:27) interpreteer die trompet op tweërlei wyse. Aan die een kant beklemtoon die trompet die majesteit van die teofanie; aan die ander kant is die trompet die teken van die finale oorgang van die teofanie na die offer in Eksodus 24:4-5. Barth (1991:121-122) interpreteer die ramshoring as 'n teken van die koms van die Here in krag. Houtman (1997:48-49) verklaar die ramshoring as van hemelse herkoms; die Here is by sy koms vergesel van 'n hemelse leërskare wat ook medeverantwoordelik is vir die kosmiese gebeure waarmee die teofanie gepaard gaan. Preuss (1995:67) dink in terme van aanbidding in sy interpretasie van die ramshoring.

Die geluid van donderweer beteken in teofanietekste dikwels die kragtige krygerstem van Jahwe of sy magvolle kreet, terwyl die weerlig gesien word as gevaarlike pyle wat Hy kan afskiet. Hierdie kosmiese verskynsels wat gepaard gaan met 'n teofanie word ook in ander dele van die Ou Testament aangetref (vgl. byvoorbeeld Ps. 18:8-16; Nah. 1:3-5; Hab. 3:3-15).

Die komende teofanie verg ook voorbereiding van die volk. Moses kry die taak om na hulle te gaan met die opdrag om hulle te reinig, hulle klere te was en hulle gereed te maak vir die teofanie (Eks. 19:14).

\subsubsection{Die doel van die teofanie}

Die verskynsels wat beskryf word, is 'n demonstrasie van die onvergelyklike en onweerstaanbare majesteit van die Here. Houtman (1997:48) merk verder op: "Een enigzins adequate indruk van de overweldigende nabijheid van de Here valt slechts te geven door middel van uiteenlopende schilderingen". Die reaksie van die volk is een van bewing en ontsetting (Eks. 20:18). Die teofanie openbaar God aan die volk. Polak (1996:137) beskryf die doel van die Sinai-teofanie só in die taal van Deuteronomium 5:24: "Die Here ons God het ons sy mag en sy grootheid laat sien, en ons het sy stem uit die vuur uit gehoor. Vandag het ons ondervind dat God met mense praat, en hulle bly lewe" (vertaald). Die teofanie toon dus die onvergelyklike krag van Jahwe en daardeur vestig Hy ook sy Goddelike gesag (Polak, 1996:137). Vir House (1998:111) beklemtoon Eksodus 19 die heiligheid en transendensie van God.

Westermann (1978:167) wys ook op 'n belangrike funksie wat die Sinaiteofanie vir die godsdiens van Israel gehad het. Hy wys daarop dat die Sinai-teofanie die basiese elemente van 'n heilige gebeurtenis bevat: die heilige plek waar God verskyn, die heilige tyd - 'n vasgestelde tyd wat gepaardgaan met die nodige voorbereidings, die middelaarsfiguur in die 
persoon van Moses en die volk se antwoord op die verkondigde Godswoord deur die middelaarsfiguur. Vir Westermann is die doel van die teofanie nie die gee van die wet (Tora) of die verbond nie. Dit lê vir hom eerder daarin dat in die tyd na die inbesitname van die land die godsdiens van Israel nie begrond word deur 'n Godsopenbaring by een van die Kanaänitiese heiligdomme nie, maar buite die land in die woestyn by 'n berg waaraan Jahwe nie gebonde bly nie (die tempel word tog later nie by Sinai nie, maar op Sion gebou).

Dit is verder vir Westermann (1978:41) 'n beklemtoning dat Jahwe primêr die God van die geskiedenis is. Sinai as heilige plek is 'n plek onderweg na die land toe. Die heilige tye word histories gebind aan die heilsdade van Jahwe in die geskiedenis. Moses is die middelaarsfiguur, maar tegelykertyd ook die leier van die uittog uit Egipte. Die volk wat antwoord, antwoord met lof op die groot dade van God. Die Sinaigebeure verbind die godsdiens van Israel met die geskiedenis. In die godsdiens vier Israel die reddende en seënende handelinge van God.

Die doel van die teofanie kan verder beskryf word as 'n ervaring en belewing van die teenwoordigheid van die Here. Wanneer God kom, laat Hy sy teenwoordigheid voel met die oog op die eventuele sluiting van die verbond (Barth, 1991:120). Die teofanie word dan eintlik deel van die verbondseremonie (Zimmerli, 1984:71, Polak, 1996:130). In Eksodus 24 vind die maaltyd van die 70 leiers in die teenwoordigheid en onder beskerming van Jahwe plaas - 'n gebeurtenis wat tegelykertyd ook sy deelname aan die maaltyd impliseer (Polak, 1996:139).

Later in Israel se geskiedenis het die gedagte van 'n direkte koms van God soos by Sinai verdwyn. Die feeste wat gevier was, is verander in handelinge waardeur die herinnering aan die dade van Jahwe in die geskiedenis gevier is. Deur die herinnering aan wat in die verlede gebeur het, het die aanbidders die betekenis daarvan weer opnuut vir hulle toegeëien. Die gedagte aan God se koms in 'n teofanie het ook mettertyd - veral by die profete - 'n eskatologiese dimensie gekry (Clements, 1978:71).

\subsection{Verbond}

\subsubsection{Die begrip ברית}

In die loop van die ondersoekgeskiedenis was daar verskillende pogings om die begrip ברית te verstaan. Etimologies was daar pogings om die betekenis van die woord terug te voer na die woord ברד wat "om te eet" (van 'n maaltyd) beteken, of die Akkadiese woord birit, wat "tussen" in die betekenis van mediasie impliseer. Sommige navorsers het die 
betekenis van die begrip gaan soek in 'n Arabiese woord wat "sny" beteken. Daar was ook pogings om die woord te verstaan as "ketting" en ook as die seldsame woord ברה wat beteken "om te kies" of "om 'n ooreenkoms aan te gaan". Ander navorsers was weer van mening dat die woord verstaan moet word as "verpligting".

Begrich (1944:1-11) het 'n belangrike artikel geskryf waarin hy twee fases in die betekenis van die woord ברית onderskei. Aanvanklik het die woord die betekenis gehad van 'n eensydige ooreenkoms of gawe waarin die een party sy noue vriendskap aan die ander party gee en belowe. Belangrik in dié fase was die feit dat die vorm van die verbond geen verpligting of wet wat op die ontvangers gelê is, impliseer nie. 'n Latere (Kanaänitiese) vorm van die verbond het meer die betekenis van 'n tweesydige ooreenkoms, 'n kontraktuele verbond dus. In albei gevalle is die aktiwiteit van die gewer van die verbond en die passiwiteit van die ontvangers van die verbond opvallend. Die gevolg hiervan is dat daar nie ' $n$ verband gesien is tussen verbond en wet nie. In die latere verstaan van die verbond word verbond en wet egter met mekaar verbind (Clements, 1978:98-100; Zimmerli, 1984:49; Preuss, 1995:71-72).

Vir Childs (1985:94-95) is die verbond die uitdrukking van 'n vaste verhouding tussen God en sy volk. Alhoewel die taal wat gebruik is die taal van die reg is, is die verhouding nie ' $n$ verdrag soos byvoorbeeld die Hetitiese verdrae nie. Die verbond is eerder verstaan as 'n daad van genade op inisiatief van God. Verbond het ook 'n antwoord geëis van die ontvangers van die verbond. Die verbond bevat dus die elemente van belofte en bevel.

Clements (1978:101) sonder twee sake uit as van belang vir die verstaan van die verbondsbegrip in die Ou Testament. Die een saak is dat Israel se bestaan en voortbestaan as nasie afhanklik is van hulle gehoorsaamheid aan die bepalings van die verbond. Die tweede saak is dat die bepalings waaraan hulle gehoorsaam moet wees, uiteengesit word in die vorm van 'n geskrewe wet.

\subsubsection{Die sluiting, verbreking en herstel van die verbond}

Die Sinai-gebeure kan vanuit die perspektief van die verbond beskou word as die geskiedenis van die sluiting (Eks. 19-31), die verbreking (Eks. 32) en die herstel (Eks. 33-34) van die verbond (Blenkinsopp, 1997:111). 


\subsubsection{Eksodus 19}

Daar word reeds in Eksodus 19:5 verwys na die verbond, maar Eksodus 19 is nie die sluiting van die verbond nie. Houtman (1997:47) sien Eksodus 19 as 'n "intentieverklaring" wat noodsaaklik is vir die eventuele sluiting van die verbond wat dan in Eksodus 24 plaasvind. Die klem van die perikoop val op die verpligting tot gehoorsaamheid wat in die verbond gevra (gaan) word (Preuss, 1995:70). Eksodus 19:1-6 moet dus eerder verklaar word in terme daarvan dat Jahwe sy volk uitkies - 'n handeling wat op hulle die verpligting lê om Hom, hulle naaste en die wêreld te dien (Wolf-Steger, 1999:25-30).

Die inisiatief vir die sluiting van die verbond berus by Jahwe. Eksodus 19 verhaal hoe Hy die Een is wat sy volk uit Egipte verlos het, hoe Hy hulle "soos op arendsvlerke veilig gedra" het - 'n verwysing na die tog van Egipte deur die woestyn tot by Sinai. Ook die verwysing na die manier waarop Hy hulle "na My toe gebring het" dui op die berg Sinai. Eksodus 19:4 funksioneer dus as 'n opsomming van die heilsgeskiedenis van Jahwe met sy volk. Preuss (1995:74) merk in dié verband op dat die verbond sy oorsprong het by Jahwe en dat dit gerig is tot die volk as geheel en nooit tot ' $n$ indiwidu nie.

Die identiteit van die volk as verbondsgemeenskap word ook uitgespel in Eksodus 19:5-6. Die Israeliete word aangedui as die eiendom van Jahwe, 'n koninkryk van priesters en 'n nasie wat aan God gewy is. Dat die Israeliete Jahwe se eiendom is, word aangedui met die begrip שiאגלה. Daarmee word Israel getipeer as Jahwe se kosbare en persoonlike besitting. Waar die term elders in die Ou Testament gebruik word, word dit ook in 'n verbondskonteks gebruik (vgl. Deut. 7:6; 14:2; 26:18) waar dit dui op die waarde van Israel as die objek van Goddelike keuse (Dumbrell, 1984:85).

Die uitdrukking "'n koninkryk van priesters" is in die loop van die geskiedenis op verskillende maniere verstaan:

- Dit is 'n aanduiding van Israel se heiligheid aan God;

- Israel is die middelaar of tussenganger tussen die nasies;

- Israel word regeer deur priesters; en

- Israel as geheilig deur God en regeer deur priesters (Gowan, 1994:177).

Die rol wat Israel in die lig van die uitdrukking "'n koninkryk van priesters" kry, is om dit wat priesters in 'n gemeenskap doen, tussen die nasies te gaan doen (Childs, 1974:367). Priesters is mense wat voltyds diens 
lewer aan God (Leithart 1999:18-22). Priesters is mense wat die offers in Israel behartig. Offers is daar om versoening te bewerk tussen God en mens. Wanneer Israel die identiteit kry om 'n koninkryk van priesters te wees, beteken dit om versoenend op te tree in die wêreld. 'n Priester is God se verteenwoordiger by mense en die mense se verteenwoordiger by God. Brueggemann (1997:431) som dit op deur te sê dat Israel se priesterlike rol nie net daar is om die welsyn en die heling van die wêreld moontlik te maak nie, maar ook om gemeenskap tussen God en die wêreld moontlik te maak.

Die uitdrukking "heilige nasie" verwys na Israel se plek tussen die ander nasies en word net hier in die Ou Testament gebruik. Soos wat die priesters in 'n gemeenskap 'n besondere posisie in die gemeenskap inneem omdat hulle regstreeks in kontak met die godheid kan tree, so is Israel 'n heilige nasie, dit wil sê, ' $n$ volk met eie norme en pligte te midde van die ander volke waarmee hulle in aanraking kom (Houtman, 1997:45). Israel as heilige nasie verwys dus na hulle posisie as afgesonder vir diens aan God.

Die identiteit van die volk word 'n werklikheid wanneer die volk gehoorsaam is aan die oproep wat hier aan hulle gestel word. Gehoorsaamheid word gevra om die identiteit 'n werklikheid te maak (van Zyl, 1992:270).

\subsubsection{Eksodus 24}

Die werklike verbondsluiting vind plaas in Eksodus 24. Moses het al die gebooie en bepalings aan die volk bekend gemaak waarop hulle met instemming geantwoord het (Eks. 24:3; 7; vgl. ook Eks. 19:8). Die woorde en bepalings moet verstaan word as die inhoud van Eksodus 2023; daarom word dié gedeelte die Bondsboek genoem na aanleiding van Eksodus 24:7.

Aan die voet van die berg het Moses 'n altaar gebou van twaalf klippe, verteenwoordigend van die twaalf stamme van Israel. Bulle is as brandoffers en maaltydoffers geoffer. Die helfte van die bloed het Moses in bakke gehou en die ander helfte het hy op die altaar gesprinkel. Die bloed in die bakke het Moses toe op die volk gesprinkel om hulle te herinner dat dit die bloed is van die verbond wat die Here met hulle gesluit het op grond van die gebooie. Die beskrywing van hierdie ritueel is uniek in die Ou Testament.

Die feit dat Moses die inhoud van die gebooie en die bepalings twee keer aan hulle voorhou en dit ook neerskryf (verse $3,4,7$ ), beklemtoon die ernstige aard van die geleentheid en dat die volk presies moet weet waarvoor hulle hulleself nou inlaat. Die wette en gebooie word dan ook 
later (in vers 12) op plat klippe deur Jahwe aan Moses gegee. Dat die gebooie op klippe deur die Here self gegraveer is, dui op die gesag waarmee die gebooie bejeën moet word en op die permanensie van die gebooie - hulle is letterlik ingegraveer op klip (Blenkinsopp, 1997:118119). Twee keer antwoord die volk dit ook met 'n plegtige verklaring van hulle gehoorsaamheid.

Die simboliek van die bloed word ook verskillend geïnterpreteer. Daar is die teorie dat die bloed 'n familie-eenheid met Jahwe suggereer. Die ander moontlikheid is dat die bloed dui op die heiliging en reiniging van die volk as toegewy aan Jahwe. Hierdie interpretasie sluit aan by Levitikus 8 waarin beskryf word hoe Aäron en die priesters met bloed geheilig word vir diens aan die Here. Die heiliging sou ook kon dien as 'n terugverwysing na Eksodus 19:5-6 waar die identiteit van die volk aangedui word as ' $n$ heilige nasie. In elke geval is die bloed daar ter beseëling van die verbond.

Eksodus 24:9-11 verhaal hoe 70 leiers van die volk die berg uitgeklim het en in die teenwoordigheid van Jahwe 'n maaltyd genuttig het. Die bedoeling met die eet van 'n maaltyd was om die nuwe en noue verhouding wat daar tot stand gekom het, te onderstreep. Die noue verhouding word uitgedruk in die verslag van die gesig wat hulle van God gesien het - ook uniek in die Ou Testament. Noudat Israel in gemeenskap met die Here leef, stel Hy Israel in staat om Hom persoonlik te ontmoet en plaas as sodanig die seël op die verbond wat pas gesluit is (Zimmerli, 1984:53; Houtman, 1995:131). Dit is interessant dat geen beskrywing van God self gegee word nie - die plek onder sy voete word beskryf. Die afleiding wat Houtman (1997:131) daaruit maak, is dat God self onbeskryflik heilig en verhewe moet wees. Die veronderstelling is verder dat God self op ' $n$ troon in die hemel sit en dat die berg die plek is waar hemel en aarde ontmoet - vandaar net die beskrywing van dit wat onder die voete van Jahwe was. Jahwe verbind Hom dus met 'n regsgeldige dokument (die Bondsboek) aan sy volk. Dit gaan gepaard met ' $n$ ritueel van offers met die besprinkeling van bloed en met die teken van 'n maaltyd wat in sy teenwoordigheid geniet word.

Niehaus (1995:198) sien 'n interessante simboliek in die res van Eksodus 24. Na die eet van die gemeenskapsmaal het Moses alleen die berg verder opgegaan. Vir 'n periode van ses dae het 'n wolk die berg bedek en op die sewende dag het Jahwe vanuit die wolk na Moses geroep (Eks. 24:15-18). Die sesdaelange periode, gevolg deur die sewende dag waarop Jahwe met Moses gepraat het, laat Niehaus (1995:198) dink aan die skepping. Die Eksodusgebeure en die sluiting van die verbond hier by Sinai is simbolies van die skepping van 'n nuwe 
bevryde Israel. Tegelykertyd beteken dit ook dat Jahwe die Skepper van Israel is.

\subsubsection{Eksodus 34}

Eksodus 32-34 is eintlik 'n Fremdkörper in die verhaal van die Sinaigebeure. Dit onderbreek die gedeelte van hoofstukke 25-31 waarin bepalings oor die oprig van die heiligdom gegee word en hoofstukke 35-40 wat handel oor die oprig van die heiligdom. Na die sluiting van die verbond in Eksodus 24 het Moses volgens Eksodus 24:18 "die wolk ingegaan en nog verder boontoe uitgeklim" en nog veertig dae en nagte daar gebly om verdere openbarings van Jahwe te ontvang. Terwyl Moses hiermee besig was, pas na die sluiting van die verbond in die teenwoordigheid van Jahwe en met herhaaldelike versekerings van die kant van die volk dat hulle hulle sal hou by die bepalings van die verbond, vind die insident van die goue kalf plaas.

Dié gedeelte bring 'n verskeidenheid teologiese temas na vore: die figuur van Moses met sy middelaarswerk tussen God en die volk (Barbiero, 2000:155-158), die probleem van die voortgesette teenwoordigheid van God na die verbondsverbreking van die volk met die bou van die goue kalf, die vraagstuk van vergiffenis, die verband tussen God se geregtigheid en sy barmhartigheid.

Die drie hoofstukke is waarskynlik saamgestel uit baie tradisies. Hierdie afleiding word gemaak op grond van die inkonsekwenthede wat in die verhaal opduik. Byvoorbeeld, nadat die Leviete op bevel van Moses 3000 mense om die lewe gebring het (vgl. Eks. 32:28), moet Moses nog steeds pleit vir sondevergiffenis en besluit die Here dat Hy nog gaan rekenskap eis en die volk sal straf oor hulle sonde (Eks. 32:34-35).

Nadat Moses by verskillende geleenthede gepleit het vir die voortbestaan van die volk en vir die behoud van die verbond, word die versoek toegestaan en die verbondsherstel vind plaas in Eksodus 34 . Nadat die aanvanklike kliptafels vernietig is, word nuwe kliptafels geskryf (Eks. 34:1). Die Here bewys Hom inderdaad as "die barmhartige en genadige God, lankmoedig, vol liefde en trou" (Eks. 34:6). Hy "vergewe ongeregtigheid, oortredings en sonde", maar spreek niemand sonder meer vry nie. Wie in verhouding met God leef, leef in die spanningsveld van God se oorweldigende barmhartigheid en geregtigheid (Houtman, 1997:243-244). Met die verbondsluiting in Eksodus 34:10 word die verbond weer van nuuts af gesluit. 


\subsubsection{Die verbondsformule}

Die sogenaamde verbondsformule lui: "Ek sal vir jou 'n God wees en jy sal My volk wees". Verskillende dele van die formule word in die Ou Testament gevind, soos byvoorbeeld "My volk", "die volk van Jahwe", "jou God", "die God van Israel" wat almal uitdrukkings van die verbond tussen Jahwe en sy volk is. Die teenwoordigheid van die Here maak dit duidelik dat die lewe algeheel in verhouding met die Here geleef word. Die lewe word geleef binne die ruimte van die verbond as 'n lewe van gehoorsaamheid aan die bepalings van die verbond. Die gehoorsaamheid aan die verbond het betrekking op die kultiese en etiese dimensies van die verbond. Die bepalings van die verbond het te doen met reëlings aangaande die regte aanbidding van Jahwe en dit moet gehoorsaam word. Die bepalings van die verbond het ook te doen met die manier waarop daar teenoor die naaste in verskillende situasies opgetree word - en dit moet eweneens gehoorsaam word.

\subsubsection{Samevatting}

Die term verbond is by uitstek 'n verhoudingsbegrip. Die sogenaamde verbondsformule "Ek sal vir jou 'n God wees en jy sal My volk wees" toon aan dat die term verbond primêr die verhouding tussen God en sy volk uitdruk. Opsommenderwys kan die verbond in die Sinai-tradisie dus vanuit die perspektief van God en vanuit die perspektief van die volk beskou word.

\subsection{Tora}

Die bevryding uit Egipte en die sluiting van die verbond het ook vir die volk verpligtings meegebring. Hierdie verpligtings is in die Tora vir hulle gegee.

\subsubsection{Die begrip Tora}

Dié begrip word gewoonlik verstaan as onderrig, instruksie, lering, veral dan godsdienstige onderrig en lering. Die Tora dek 'n wye veld: dit handel oor kultiese voorskrifte insake die korrekte aanbidding van Jahwe en die beskerming van die heiligdom van die tempel, maar dit bevat ook reëlings in verband met die gesondheid van die gemeenskap, rein en onrein voedsel, seksuele verhoudings en sosiale gebruike. Daar kan dus geen eng definisie van die begrip Tora wees nie. Tora is die omvattende lys van bepalings waardeur die verbond van Irael met God beheer word (Clements, 1978:110). Dumbrell (1984:91) verstaan die term as 'n "direction of life within the framework of the presupposed relationship". Smith (1997:269) toon aan hoe die term Tora nie net "wet" in die regstegniese betekenis van die woord aandui nie, maar inderdaad 'n wye 
spektrum ander materiaal, soos byvoorbeeld priesterlike onderrig, kultiese kalenders en ander materiaal wat nie as "wet" verstaan kan word nie. Dit is uit die definisies duidelik dat Tora nie verstaan kan word as "wet" nie. Die Tora gee die rigting aan vir wat verwag word van mense wat hulle lewens binne die ruimte van die verbond inrig.

Die begrip Tora (תשראשת, (תשרה) is ook net een van verskillende begrippe wat gebruik is om die wet van God mee aan te dui. Die

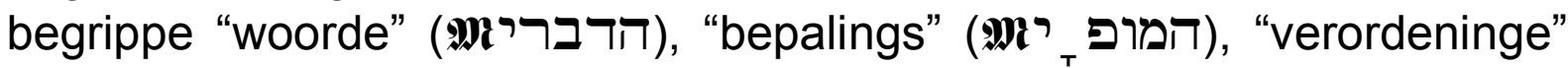

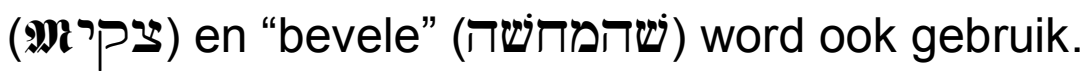

\subsection{2 'n Raamwerk vir die verstaan van die Tora}

Die Tora kan nie van die reddingsdade van God in die geskiedenis losgemaak word nie (Westermann, 1978:157). Dit wys die inleiding tot die dekaloog: "Ek is die Here wat jou uit Egipte, die plek van slawerny, bevry het" (Eks. 20:2). Die Tora word gegee nadat die volk die redding van God in die geskiedenis ervaar het. Die Tora word ook gegee as deel van God se geskiedenis met sy volk. Die Tora word op dié manier nie net gekoppel aan die heilsgeskiedenis van die volk nie; dit word self ook deel van die heilsgeskiedenis van die volk.

Die Tora moet ook verstaan word binne die konteks van die teofanie. Telkens na die teofanie volg die bepalings van die Tora. Na die teofanie van Eksodus 19 volg die Tora van Eksodus 20. Na die teofanie van Eksodus 24:15-18 volg die Tora van Eksodus 25 - 40.

Die Tora kan ook nie los van die verbond verstaan word nie. Die Tora van die Bondsboek in Eksodus 20-23 word omraam deur die vermelding van die verbond in Eksodus 19:5 en die sluiting van die verbond in Eksodus 24. Sprinkle (1994:27) toon aan hoe Eksodus 19-24 'n chiastiese struktuur vertoon:

A Narratief, die verbond aangebied (Eks. 19)

B Algemene reëls, die dekaloog (Eks. 20:1-17)

C Narratief, die volk se vrees vir die Here (Eks. 20:18-21)

B Spesifieke reëls (Eks. 20:22-23:33)

A Narratief, die verbond word gesluit (Eks. 24)

Die implikasie hiervan is dat die Tora net verstaan kan word binne die raamwerk van die verbond. In 'n sekere sin sou 'n mens selfs kon sê die Tora word ondergeskik gestel aan die verbond. Die nou verband tussen verbond en Tora druk Barth (1991:124) só uit: "In revealing his laws God concluded his covenant, and in concluding his covenant he revealed his laws". Dit is ook die standpunt van Childs (1974:382): “... law and 
covenant belong together ... there can be no seperation theologically between the two". Die raamwerk van die verbond waarbinne die Tora staan, verhoed dat die Tora verander in 'n stuk wettisisme en die Tora verseker weer ' $n$ verbond met ' $n$ inhoud. Die Tora gee aanwysings vir die lewe binne die raamwerk van die verhouding wat die verbond tussen God en sy volk tot stand gebring het.

Dit is ook belangrik om raak te sien dat die voorskrifte van die Tora nie gegee word sodat mense in 'n verhouding met Jahwe, die Verbondsgod, kan leef nie. Die voorskrifte van die Tora word gegee omdat mense alreeds in 'n verbondsverhouding met die Here leef. Dit gaan dus in die voorskrifte van die Tora nie oor 'n weg om by God uit te kom nie, maar oor 'n weg vir hulle wat reeds uit genade verlos is en sy volk gemaak is, om dankbaar en met oorgawe voor hulle Here te lewe en te bly lewe (Kloppers, 1982:6).

\subsubsection{Die inhoud en teologiese funksie van die Tora}

Die Tora bevat die lewensreëls van die lewe van die volk van God binne die ruimte van die verbond. Breedweg gesien, handel die Tora oor die regte aanbidding en verering van Jahwe en oor die hantering van menseverhoudings. Die volk se kultiese en etiese verpligtings is wat hier onder die loep kom en wat geillustreer word in die boek Levitikus. Die Bondsboek begin (Eks. 20:22-23:33) en eindig (Eks. 23:10-19) ook met bepalings oor die aanbidding van Jahwe terwyl dit ook uitgebreide bepalings bevat oor die hantering van mense en menseverhoudinge.

Die implikasie van die strukturering is dat die verhouding met Jahwe die verhouding met die naaste bepaal. Alle nadruk val eers op die juiste verering van Jahwe (Houtman, 1997:80). Die verbond is in die eerste plek ' $n$ verbond wat tot stand kom tussen Jahwe en die volk en daarom sal die bepalings rondom die reëling van die verhouding tussen Jahwe en sy volk en hulle aanbidding van Hom voorrang kry. Die bepalings wat betrekking het op die verhouding met die naaste dien as aanmoediging tot 'n lewe van moreel hoogstaande en barmhartige gedrag (Houtman, 1997:81). Die Bondsboek kan dus nie beskou word as 'n wetboek nie, maar eerder as 'n instrument om die samelewing te orden. Sprinkle (1994:84-88) toon aan hoe die bepalings wat betrekking het op mense en menseverhoudings die klem eerder plaas op morele en humane reëlings as op 'n streng wettiese nakom van 'n bepaling in 'n wetboek. Die aksent wat in die Tora op die reëling van menseverhoudings gelê word, is belangrik. Daardeur word die "gewone" aardse lewe binne die kader en invloedsfeer van die verhouding met Jahwe geplaas. Naastediens word dus ook godsdiens. Die groot aantal wette oor allerlei 
godsdienstige en burgerlike sake stempel ook die identiteit van die volk as volk van God.

\subsubsection{Die plek van die dekaloog in die Tora}

Die dekaloog beklee 'n besondere plek in die raamwerk van die tora wat op Sinai gegee is. Die dekaloog is die eerste van die Tora wat aan die volk gegee word. Die dekaloog is ook die enigste woorde wat die volk direk van Jahwe hoor, die ander bepalings het hulle via Moses gehoor. Die dekaloog se uitsonderingsposisie word verder onderstreep deur die feit dat die dekaloog bekend word as die "tien woorde" van God. Dit is merkwaardig dat Eksodus 20:1 lees: "Toe het God al hierdie woorde gesê". (Die 1933/53-vertaling van die Afrikaanse Bybel is dus hier nader aan die teologiese bedoeling van die teks as die 1983-vertaling wat "gebooie" in plaas van "woorde" vertaal.) Die dekaloog is ook omraam deur ' $n$ teofanie wat in Eksodus 19:16-20 beskryf word en in Eksodus 20:18-21 verder beskryf word.

\section{Slot}

Dit is duidelik dat die Sinai-gebeure nie alleen 'n prominente plek in die Pentateug inneem nie, maar ook 'n belangrike teologiese tradisie in die res van die Ou Testament is. Sinai is die plek waar Jahwe Hom en sy wil (die Tora) op 'n besondere manier aan sy volk geopenbaar het in 'n teofanie en dit is die plek waar die verbond gesluit is.

\section{Bibliografie}

BARBIERO, G. 2000. Ex xxxiii 7-11: eine synchrone Lektüre. Vetus Testamentum, 50:152-166.

BARTH, C. 1991. God with us. A theological introduction to the Old Testament. Michigan : Eerdmans.

BEGRICH, J. 1944. "Berit". Zeitschrift für die Alttestamentliche Wissenschaft, 60:111.

BIRCH, B.C., BRUEGGEMANN, W., FRETHEIM, T.E. \& PETERSEN, D.L. 1999. A theological introduction to the Old Testament. Nashville : Abingdon.

BLENKINSOPP, J. 1997. Structure and meaning in the Sinai-Horeb narrative. (In Carpenter, E.E., ed. A biblical itenerary. In search of method, form and content. Essays in honor of G.W. Coats. Sheffield : Sheffield Academic Press. p. 109125.) (JSOT SS 240.)

BRUEGGEMANN, W. 1997. Theology of the Old Testament - testimony - dispute advocacy. Minneapolis : Fortress.

CHILDS, B. S. 1974. Exodus - A commentary. London : SCM.

CHILDS, B.S. 1985. Old Testament theology in a canonical context. London : SCM.

CLEMENTS, R.E. 1978. Old Testament theology. A fresh approach. London : Marshall, Morgan \& Scott.

DOZEMAN, T.B. 1989. God on the mountain. A study of redaction, theology and canon in Exodus 19-24. Atlanta : Georgia. (SBLMS 37.) 
DUMBRELL, W.J. 1984. Covenant and creation. An Old Testament covenantal theology. Devon: Paternoster.

EICHRODT, W. 1975. Theology of the Old Testament. Vol I, II. London : SCM.

GOWAN, D.E. 1994. Theology in Exodus. Biblical theology in the form of an commentary. Louisville : Westminster John Knox Press.

HOUSE, P.R. 1998. Old Testament theology. Downers Grove : InterVarsity Press.

HOUTMAN, C. 1997. Exodus II. Een praktische bijbelverklaring. Kampen : Kok. (Teks en toelichting.)

JEREMIAS, J. 1965. Theophanie; Die Geschichte einer alttestamentlichen Gattung. Neukirchen-Vluyn : Neukirchener. (WMANT 10.)

KLOPPERS, M.H.O. 1982. Die aktualiteit van die boodskap van Levitikus vir die Christelike kerk. Bloemfontein : UOVS.

LEITHART, P.J. 1999. Attendants of Yahweh's house: priesthood in the Old Testament. Journal for the Study of the Old Testament, 85:3-24.

NIEHAUS, J.J. 1995. God at Sinai. Covenant and theophany in the Bible and Ancient Near East. Carlisle : Paternoster. (Studies in Old Testament Biblical Theology.)

POLAK, F. 1996. Theophany and mediator: The unfolding of a theme in the Book of Exodus. (In Vervenne, M., ed. Studies in the Book of Exodus. Redaction reception - interpretation. Leuven : Leuven University Press. p. 113-148.)

PREUSS, H.D. 1995. Old Testament theology. Vol. I. Louisville : Westminster John Knox Press.

SMITH, M.S. 1997. The pilgramage pattern in Exodus. Sheffield : Sheffield Academic Press. (JSOT SS 239.)

SPRINKLE, J.M. 1994. The Book of the covenant - A literary approach. Sheffield : Sheffield Academic Press. (JSOT SS 174.)

VAN ZYL, D.C. 1992. Exodus 19:3-6 and the kerugmatic perspective of the Pentateuch. Old Testament Essays, 5(2), 264-271.

VON RAD, G. 1975. Old Testament theology. Vol. I. London : SCM.

WESTERMANN, C. 1978. Theologie des Alten Testaments in Grundzügen. Göttingen : Vandenhoeck \& Ruprecht. (ATD Ergänzungsreihe 6.)

WOLF-STEGER, A. 1999. Auf Adlersflügeln - Die Erwählung Israels am Sinai: Exegese zu Exodus 19:1-6. Texte \& Kontexte, 22(3):14-38.

ZENGER, E. 1996a. Die Tora/ der Pentateuch als ganzes. (In Zenger, E., Hrsg. Einleitung in das Alte Testament. 2. Auflage. Stuttgart : Kohlhammer. p. 34-75.)

ZENGER, E., Hrsg 1996b. Einleitung in das Alte Testament. 2. Auflage. Stuttgart : Kohlhammer.

ZIMMERLI, W. 1984. Old Testament theology in outline. Edinburgh : Clark.

\section{Kernbegrippe:}

Sinaitradisie

teofanie

Tora

verbond

Key concepts:

covenant

Sinai tradition

theophany

Torah 